\title{
Penggunaan Shock Index sebagai Prediktor MODS pada Pasien Multi- trauma di RSUP Prof. Dr. R. D. Kandou Manado
}

\author{
${ }^{1}$ Yan Senjaya, ${ }^{2}$ Ishak Lahunduitan, ${ }^{3}$ Djony Tjandra
}

\author{
${ }^{1}$ PPDS Ilmu Bedah Fakultas Kedokteran Universitas Sam Ratulangi Manado \\ ${ }^{2}$ KSM Ilmu Bedah Anak RSUP Prof. Dr. R. D. Kandou Manado \\ ${ }^{3}$ KSM Ilmu Bedah Divisi Bedah Toraks Kardiovaskular RSUP Prof. Dr. R. D. Kandou \\ Manado \\ Email: fx_yan_senjaya@yahoo.com
}

\begin{abstract}
Multiple organ dysfunction syndrome (MODS) is the leading cause of mortality in patients that still survive in several hours post trauma. Shock index (SI) has been proved to be useful in the early diagnosis of acute hypovolemia in normal blood pressure and pulse condition. It is used to determine the severity of injury and poor outcome in traumatic patient. This study was aimed to obtain the cut-off point ratio of SI which can be used to predict the occurence of MODS and to determine the sensitivity and specificity of SI as a predictor of MODS in multitrauma patients at Prof. Dr. R. D. Kandou Hospital Manado. This was a diagnostic test study with a cross sectional design conducted from Febuary 2016 to May 2017. Population and samples were all multitrauma patients during that period of time that met the inclusion criteria. Data were analyzed by using cut-off point analysis to obtain the area under curve (AUC), as well as the sensitivity and specificity of SI to MODS. There were 150 multitrauma patients in this study, most were males, with the mean age of 33.99 years. The mean ISS was 28.4, SIRS as many as $68.66 \%$, and the mean shock class was 1.4. There were 63 patients with MODS, 37 patients needed PRC transfusion, and 16 patients died. The AUC 80.5\% (95\% CI 73.0-88.0\%; $P=0.000$ ); SI 0.950588 with the sensitivity $74.6 \%$ and specificity $78.2 \%$ to MODS. The AUC 74.1\% (95\% CI 61.1-87.2\%; $P=$ 0.002 ); SI 0.97559 with $75.0 \%$ sensitivity and $64.2 \%$ spesificity to death. Conclusion: Shock index can be used as a predictor of the occurence of MODS and death in multi-trauma patients.
\end{abstract}

Keywords: SI, MODS, multitrauma

\begin{abstract}
Abstrak: Multiple organ dysfunction syndrome (MODS) merupakan penyebab utama mortalitas pada pasien yang selamat dalam beberapa jam setelah trauma. Shock index (SI) bermanfaat untuk mendiagnosis awal hipovolemia akut pada keadaan tekanan darah dan nadi yang normal dan digunakan sebagai penanda keparahan suatu cedera dan keluaran yang buruk untuk pasien trauma. Penelitian ini bertujuan untuk mendapatkan cut off point ratio SI yang dapat digunakan sebagai pedoman untuk memrediksi terjadinya MODS dan menentukan sensitivitas dan spesifitas SI sebagai prediktor MODS pada pasien multitrauma di IRDB RSUP Prof. Dr. R. D. Kandou, Manado. Jenis penelitian ialah uji diagnostik dengan desain potong lintang yang dilakukan mulai bulan Febuari 2016 sampai Mei 2017. Populasi dan sampel ialah semua pasien multitrauma yang memenuhi kriteria inklusi. Analisis data menggunakan analisis cut-off point serta mencari area under curve (AUC), sensitivitas, dan spesifitas instrumen SI terhadap MODS. Terdapat 150 pasien multitrauma dalam studi ini, sebagian besar berjenis kelamin laki-laki dengan rerata usia 33,99 tahun. Rerata ISS 28,4, SIRS sebanyak 68,66\%, dan rerata syok kelas 1.4. Terdapat 63 pasien multitrauma mengalami MODS, 37 pasien memerlukan transfusi PRC, dan 16 pasien meninggal. Nilai AUC 80,5\% (95\% interval kepercayaan [IK] 73,0-88,0\%; $P=0,000$ ); SI 0,950588 dengan sensitivitas $74,6 \%$ dan spesifisitas $78,2 \%$ terhadap MODS. Nilai AUC 74,1\% (95\% interval kepercayaan [IK] 61,1-87,2\%; $p=0,002$ ); SI 0,97559 memiliki sensitivitas 75,0\% dan spesifisitas $64,2 \%$ terhadap terjadinya kematian. Simpulan: Shock index dapat digunakan sebagai prediktor terjadinya MODS dan kematian pada pasien dengan multitrauma.
\end{abstract}

Kata kunci: SI, MODS, multitrauma 
Multiple organ dysfunction syndrome (MODS) merupakan penyebab utama mortalitas pada pasien yang selamat dalam beberapa jam setelah trauma. ${ }^{1}$ Shock index (SI) telah dibuktikan berguna untuk mendiagnosis awal hipovolemia akut pada pengukuran tekanan darah dan nadi yang normal dan digunakan sebagai penanda keparahan suatu cedera dan keluaran yang buruk pada pasien trauma. Shock index dapat menjadi alat yang bernilai untuk mengenali dan mengevaluasi penyakit kritis secara dini di unit gawat darurat (UGD) sehingga resusitasi pada pasien dapat dilakukan lebih awal. Konsekuensi dari pengenalan yang terlambat terhadap tanda-tanda sepsis termasuk kehilangan darah yang aktif dan inflamasi mikrosirkulasi dapat memicu terjadinya disfungsi organ. ${ }^{2}$

Penelitian ini bertujuan untuk mendapatkan cut off point ratio SI yang dapat digunakan sebagai pedoman untuk memrediksi terjadinya MODS dan menentukan sensitivitas dan spesifitas SI sebagai prediktor MODS pada pasien multitrauma di Instalasi Rawat Darurat Bedah (IRDB) RSUP Prof. Dr. R. D. Kandou, Manado.

\section{METODE PENELITIAN}

Penelitian ini merupakan uji diagnostik dengan desain potong lintang yang dilakukan di IRDB RSUP Prof. Dr. R. D. Kandou, Manado, mulai bulan Febuari 2016 sampai dengan April 2017.

Populasi dan sampel ialah semua pasien multitrauma yang memenuhi kriteria inklusi, yaitu semua pasien multitrauma yang datang ke IRDB RSUP Prof. Dr. R. D. Kandou, Manado, berusia 14-60 tahun, jenis kelamin laki-laki dan perempuan, serta bersedia mengikuti penelitian dan mengisi formulir persetujuan. Kriteria eksklusi yaitu pasien yang hanya mengalami trauma pada satu region tubuh, menderita penyakit sistemik di luar trauma, dan cedera kepala berat (GCS $\leq 8)$.

Analisis data menggunakan analisis cut-off point serta mencari area under curve (AUC), sensitivitas dan spesifitas instrumen SI terhadap MODS.

\section{HASIL PENELITIAN}

Selama bulan Februari 2016 sampai dengan April 2017 didapatkan 150 pasien multitrauma yang memenuhi kriteria inklusi dan menjadi sampel penelitian. Rerata usia ialah 33,99 tahun dan sebagian besar berjenis kelamin laki-laki (86,7\%, sebanyak 130 pasien). Rerata ISS 28,4, dan sampel yang mengalami SIRS sebanyak 68,66\% (103), dengan rerata shock kelas 1.4 (Tabel 1).

Dari semua sampel multitrauma, 63 pasien (42\%) mengalami MODS, 37 pasien (24,66\%) memerlukan transfusi PRC dengan rerata transfusi sebanyak 2,54 kantong (230 cc/kantong). Rerata rawat inap pasien dengan multitrauma sebanyak 9,52 hari, dengan rerata rawat inap ICU sebanyak 1,20 hari (Tabel 1).

Dari hasil penelitian juga diperoleh rerata SI dari keseluruhan sampel ialah 1,0011. Pada pasien MODS, rerata SI ialah 1,20201 . Pasien dengan multitrauma yang meninggal sebanyak 16 pasien (Tabel 1).

Tabel 1. Karakteristik sampel penelitian

\begin{tabular}{ll}
\hline Variabel & Hasil \\
\hline Usia & $33,99 *$ \\
Jenis kelamin; laki-laki $:$ & $130(86,7 \%)$ : \\
perempuan & $20(13,3 \%)$ \\
Durasi prahospital (jam) & $4,72 *$ \\
ISS & $28,4 *$ \\
SIRS & $103(68,66 \%)$ \\
Syok $\quad$ PRC pasien & $37(24,66 \%)^{*}$ \\
Transfusi & \\
MODS & $63(42 \%)$ \\
MODS & $16(10,66 \%)$ \\
Meninggal & 9,52 \\
Masa rawat inap (hari) & \\
Perawatan ICU (hari) & 1,20 \\
*nilai rerata & \\
ISS, injury severity score; SIRS, systemic \\
inflammation response syndrome; MODS, \\
multiple organ dysfunction syndrome \\
\hline
\end{tabular}

Nilai area under curve (AUC) 80,5\% (95\% interval kepercayaan [IK] 73,088,0\%; $P=0,000$ ) menunjukkan instrumen SI mempunyai simpulan yang tepat dalam menilai terjadinya MODS pada 805 dari 1000 orang (80,5 dari 100 orang). Pada SI 0,950588 didapatkan nilai cut off yang 
paling optimal untuk sensitifitas $74,6 \%$ dan spesifisitas 78,2\% terhadap MODS (Gambar 1).

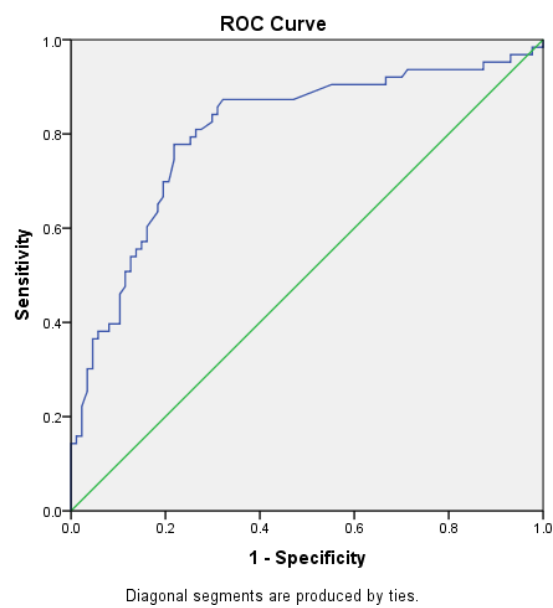

Gambar 1. Nilai AUC 80,5\% untuk SI terhadap terjadinya MODS. Pada SI 0,950588 didapatkan nilai cut off yang paling optimal untuk sensitifitas $74,6 \%$ dan spesifisitas $78,2 \%$ terhadap MODS.

Nilai AUC 74,1\% (95\% interval kepercayaan [IK] 61,1\% - 87,2\%; $p=0,002$ ) yang menunjukkan SI mempunyai simpulan yang tepat dalam menilai terjadinya kematian pada 741 dari 1000 orang (74,1 dari 100 orang). Pada SI 0,97559 didapatkan nilai cut off yang paling optimal untuk sensitifitas (75,0\%) dan spesifisitas $(64,2 \%)$ terhadap terjadinya kematian (Gambar 2).



Gambar 2. Nilai AUC $74,1 \%$ untuk SI terhadap terjadinya MODS. Pada SI 0,97559 didapatkan nilai cut off yang paling optimal untuk sensitifitas $(75,0 \%)$ dan spesifisitas $(64,2 \%)$ terhadap terjadinya kematian

\section{BAHASAN}

Selama Februari 2016 sampai dengan April 2017 terdapat 150 pasien multitrauma yang memenuhi kriteria inklusi dan menjadi sampel penelitian. Rerata usia ialah 33,99 tahun dengan sebagian besar (86,7\%) berjenis kelamin laki-laki. Kisaran usia ini merupakan usia produktif dimana sebagian besar orang memiliki tingkat mobilitas yang tinggi menggunakan kendaraan bermotor. Hal ini sejalan dengan penelitian yang dilakukan oleh Riyadina et al. ${ }^{3}$ yang mendapatkan data kelompok usia dewasa (15-59 tahun) sebesar 43,54\% di Indonesia dengan persentase laki-laki dibandingkan perempuan sebesar 59,16\% : 40,84\%. Mayoritas laki-laki beraktivitas di luar rumah untuk bekerja sehingga berisiko lebih tinggi mengalami cedera. Melihat kondisi tersebut maka perlu dipikirkan program pencegahan yang efektif sesuai dengan karakteristik masing-masing.

Dari seluruh sampel pasien multitrauma didapatkan rerata skor ISS sebesar 28,4 (Tabel 1), yang menunjukkan pasien memiliki angka prediksi mortalitas semakin tinggi. Hal ini sesuai dengan Senkowski dan McKenney ${ }^{4}$ yang menyatakan bahwa ISS dengan skor $\geq 16$ memiliki angka mortalitas sebesar $10 \%$.

Secara keseluruhan, pada pasien multitrauma didapatkan systemic inflammation response syndrome (SIRS) sebanyak $68,66 \%$, yang terjadi sebagai suatu respon trauma dimana terdapat pelepasan mediator-mediator pro dan anti inflamasi. Kondisi ini dapat terjadi di awal trauma dengan adanya peningkatan kadar neutrofil pada 3-24 jam pertama, mencapai puncak pada hari ke 2, dan kembali ke kadar normal pada hari ke 6-7. ${ }^{5-7}$ Rerata waktu yang dibutuhkan pasien untuk datang ke rumah sakit ialah 4,72 jam, dimana SIRS sudah terjadi.

Pasien multitrauma yang datang umumnya dengan syok kelas 1.43. Perdarahan pasca trauma yang tidak terkontrol merupakan salah satu penyebab kematian yang seharusnya bisa di cegah. Oleh karena itu American College of Surgeons membagi syok menjadi 4 kelas 
dengan kelas 1 dimasukkan dalam kriteria tidak syok. Hal ini selaras dengan penelitian oleh Frohlich et al. ${ }^{8}$ yang menilai adanya syok yang pada kriteria ATLS tidak terdeteksi, sedangkan dengan pemeriksaan SI dapat dinilai lebih awal.

Dalam penelitian ini terdapat 63 pasien multitrauma yang mengalami MODS. Secara umum, penyebab MODS setelah trauma meliputi berbagai faktor seperti: pasien, cedera yang dialami, dan terapi yang diperoleh. Disregulasi respon imunologi merupakan faktor penting pada patofisiologi terjadinya MODS pasca trauma. MODS berhubungan dengan angka kematian yang tinggi yaitu 27-100\%, tergantung pada jumlah organ yang terlibat. Hal ini sesuai dengan hasil penelitian ini yang mendapatkan kematian sebanyak 15 pasien (23,80\%). Pasien MODS yang tidak tertangani dengan baik akan berlanjut menjadi MOF yang berakibat lanjut dengan kematian. ${ }^{1}$

Pada SI 0,950588 didapatkan nilai cut off yang paling optimal untuk sensitivitas $74,6 \%$ dan spesifisitas 78,2\% terhadap MODS. Shock index adalah rasio denyut jantung (HR) dibagi tekanan darah sistolik (SBP), dimana telah dinyatakan sebagai penanda syok dan SI telah dihubungkan dengan derajat syok, penurunan oksigenasi jaringan, dan performa ventrikel kiri. SI normal berkisar antara 0,5-0,7. ${ }^{9}$ Respon pertahanan tubuh terhadap trauma yaitu dengan memroduksi dan melepaskan mediator-mediator lokal dan sistemik yang berbeda, seperti sitokin pro inflamasi, faktor komplemen, protein pada fase kontak dan sistem koagulasi, protein fase akut, mediator neuroendokrin dan akumulasi sel-sel imunokompeten pada daerah lokal dari jaringan yang mengalami kerusakan. Selain itu mediator anti inflamasi juga dihasilkan (compensatory anti inflammatory response syndromel CARS). Ketidak seimbangan dari respon imun keduanya bertanggung jawab terhadap disfungsi organ dan meningkatkan kemungkinan terjadinya infeksi. Kondisi dengan SI >0,9 menunjukkan pasien gawat darurat yang kritis meskipun didapatkan tanda vital yang normal. ${ }^{10}$

Adanya syok menyebabkan terjadinya disfungsi organ oleh karena hipoperfusi jaringan yang disebabkan oleh hipoksia dan trauma sekunder. Disfungsi dari sistem kardiovaskular secara sistemik, regional dan mikroregional menyebabkan terjadinya ketidakseimbangan antara kebutuhan dan pasokan oksigen jaringan sehingga terjadi hipoksia jaringan, yang secara langsung dapat menyebabkan MODS. Adanya hipoksia jaringan menyebabkan respon imun, sitokin, protease, lipoksigenase dan radikal bebas menyebabkan apoptosis dan terjadi MODS. Selain itu MODS juga dapat diakibatkan oleh terjadinya pelepasan endotoksin dan eksotoksin yang diproduksi oleh bakteri. ${ }^{1,5,11}$

Pada SI 0,97559 didapatkan nilai cut off yang paling optimal untuk sensitivitas $75,0 \%$ dan spesifisitas $64,2 \%$ terhadap terjadinya kematian. Menurut Berger et al. ${ }^{2}$ SI $>0,7$ (15,8\%) memiliki nilai prognostik yang baik dalam menilai mortalitas. Hal ini sesuai dengan hasil penelitian ini yang mendapatkan angka mortalitas sebesar 22,41\% (13 pasien).

Hasil penelitian ini juga mendapatkan pasien multitrauma dengan rerata syok kelas 1,4 yaitu termasuk kriteria tidak syok, yang sering menyebabkan keterlambatan dalam penanganan syok. Menurut Frohlic et al. ${ }^{8}$ SI dapat menjadi prediktor yang lebih baik dalam hal kebutuhan transfusi darah, sehingga mencegah terjadinya hipoperfusi jaringan yang dapat menyebabkan terjadinya MODS dan meningkatkan angka mortalitas.

MODS yang terjadi dalam 48 jam pertama setelah cedera sering membaik setelah dilakukan resusitasi. Adanya disfungsi organ saat resusitasi bukan merupakan suatu syarat terjadinya MOF. MODS yang terjadi dalam 48 jam pertama menggambarkan respon fisiologik yang reversibel terhadap cedera dan resusitasi dimana dapat menjadi solusi setelah resusitasi selesai. Oleh kerena itu penanganan awal yang cepat dan tepat sangat dibutuhkan. Sesuai dengan algoritma ATLS, pemberian oksigen dan cairan 
kristaloid, koloid dan darah sangat
penting.

Setelah dilakukan survei primer dan pemeriksaan penunjang, multi-trauma di bagi menjadi non responder, borderline dan responder sesuai dengan respon awal saat dilakukan resusitasi cairan. Prosedur operasi untuk life saving, seperti dekompresi pneumotoraks, tamponade jantung, debrideman fraktur terbuka dan kontrol perdarahan intratorakal atau intrabdomen harus dilakukan tanpa keterlambatan. Intervensi awal ini dapat mengurangi terjadinya inflamasi sistemik yang dapat berlanjut pada MODS dan peningkatan angka mortalitas. Hal ini mengurangi pelepasan sistemik dari mediator pro dan anti inflamasi serta mengurangi komplikasi sepsis.

\section{SIMPULAN}

Shock index dapat digunakan sebagai prediktor terjadinya MODS dan kematian pada pasien dengan multitrauma.

\section{DAFTAR PUSTAKA}

1. Menyar AE, Thani HA, Zakaria ER, Zarour A, Tuma M, Abdulrahman $\mathbf{H}$, et al. Multiple organ dysfunction syndrome (MODS): Is it preventable or inevitable? Int J Clin Med. 2012;3: 722-30.

2. Berger T, Green J, Horeczko T, Hagar Y, Garg N, Suarez A, et al. Shock index and early recognition of sepsis in the Emergency Department: Pilot Study 2013;14:2

3. Riyadina W, Suhardi, Permana M. Pola dan determinan sosiodemografi cedera akibat kecelakaan lalu lintas di Indonesia. Maj Kedokt Indon 2009; 59:10.

4. Senkowski CK, Mckenney MG. Trauma scoring systems: a review. J Am Coll Surg. 1999;189:491-503.

5. Burch JM, Moore JB, Cothren CC, Sauaia
A, Johnson JL, Moore EE, et al. Multiple organ dysfunction during resuscitation is not post injury multiple organ failure. Arch Surg. 2004;139: 590-5.

6. Bone RC. Toward a theory regarding the pathogenesis of the systemic inflammatory response syndrome: What we do and do not know about cytokine regulation. Crit Care Med. 1996;24(1):163-72.

7. Bone RC. Immunologic dissonance: a continuing evolution in our understanding of the systemic inflammatory response syndrome (SIRS) and the multiple organ dysfunction syndrome (MODS). Ann Intern Med. 1996;125(8):680-7.

8. Frohlic M, Driessen A, Bohmer A, Nienaber $\mathbf{U}$, Igressa A, Probst $\mathbf{C}$, et al. Is the shock index based classification of hypovolemic shock applicable in multiple injured patients with severe traumatic brain injury?-an analysis of the TraumaRegister DGU. Scand J Trauma Resusc Emerg Med. 2016:24:148.

9. King RW, Plewa MC, Buderer NMF, Knotts FB. Shock index as a marker for significant injury in trauma patients. Acad Emerg Med. 1996;3(11):1041-5.

10. Keel M, Trentz O. Pathophysiology of polytrauma. Int J Care Injured. 2005; 36:691-709.

11. Vogel JA, Liao MM, Hopkins E, Seleno N, Byyny RL, Moore EE, et al. Prediction of postinjury multiple-organ failure in the emergency department: development of the Denver Emergency Department Trauma Organ Failure score. J Trauma Acute Care Surg. 2014;76(1):140-5.

12. Ruden CV, Woltmann A, Rose M, Wurm S, Ruger M, Hierholzer C, et al. Outcome after severe multiple trauma: a retrospective analysis. J Trauma Manag Outcomes. 2013;7:4. 